\title{
Gender, Tradition, and Religion in Sabriya: Damascus Bitter Sweet and Pillars of Salt
}

\author{
Wafaa H. Sorour \\ University of South Valley, Qena, Egypt
}

\begin{abstract}
The analysis of women' contribution to Arabic literature brings to light novels written by Arab women novelists whose writings reflect the intricate factors restraining women between the tradition and the codes of Islam. The Syrian writer Ulfat Idilbi and the Jordanian novelist Fadia Faqir delineate such entanglment elequently in both Sabriya: Damascus Bitter Sweet and Pillars of Salt. The paper previews some critical opinions namely of: the Egyptian American Professor of Women Studies and Religion, Leila Ahmed; the Moroccan Sociologist and writer, Fatima Mernessi; and the Algerian writer and film maker, Assia Djebar. Through manifesting theses critical views along with the two novels, the paper proposes that much of the gender inequalituy practised in the Arab societies and reflected in the two novels, might be rooted in the tradition, not the religion itself.
\end{abstract}

Keywords: Arab women, Women abuse, Sharía-social customs, Qur’an-Islamic tradition (Hadith)

The analysis of women' contribution to Arabic literature brings to light novels written by Arab women novelists whose writings reflect the intricate factors disparaging the Arab women denying them any positive national zest. This has always been claimed as dictated by the tradition or the codes of the Islam. The Syrian writer Ulfat Idilbi and the Jordanian writer Fadia Faqir strove to have their voices heard in the male-dominant culture of the Arab countries. This paper scrutinizes such assumptions manifesting some critcal views followed by examination of Sabryia: Damascus Bitter Sweet by Idilbi and Pillars of Salts by Faquir.

According to M. Hilary Lips, "There is in many cultures, including our own, a long history of a hierarchal relationship between the groups: men held more social power than women; men have been dominant and women subordinate” (Lips, 1988, p. 3). Eventually, the stigma of gender equality has almost been settled in western societies, yet, in Arab countries it is associated with both the Arabic tradition and the religion of Islam.

Prof. Leila Ahmed is keen on clarifying all the issues between religion and customs. She raises several doubts over the assumptions associated with Islam claiming women as mere impotent and subordinate to men. In her book Women and Gender in Islam, she embarks on a historical exploration into the roots of the early Arab societies ever since the pre-Islamic Middle East. She decides to include specific middle eastern regions in the core of her gender discourses, namely "Mesoptamia, Greece, Egypt and Iran” (Ahmed, 1992, p. 3). Ahmed considers examining the Islamic tradition can not be attained without regarding the prevailing ethnic, political,

Wafaa H. Sorour, Dr., lecturer of English Literature, Faculty of Arts, Qena, University of South Valley, Qena, Egypt.

An earlier version of this paper was presented at the Annual Meeting of the American Comparative Literature Association (ACLA 2017), July 6-9, 2017. 
religious, and cultural norms practised against women in these non-Muslem conqured societies.

Ahmed relates many of the misconceptions regarding Islam and the abuse of women to a process of continuity and receprocality held between the civilization of the newly arising religion and the well-established past civilizations in the region (Ahmed, 1992, p. 4).

As Ahmed digs deeper into the early societies of the Mesopotamia, she concludes one established theory about the subordination of women providing that "cultures throughout the Middle East venetrated the mother-godess in the Neolithic period, into the second millennium B.C.E. in some areas" (Ahmed, 1992, pp. 11-12). According to Gerda Lerner, urbanity and warfare demanded increase in the population in these early societies which "led to the theft of women, whose sexuality and reproductive capacity became the first 'property' that tribes competed for" (Ahmed, 1992, p. 12). This interprets how the early Mesopotamian culture began to hold a patriarchal attitude and "entrenched male dominance" (Ahmed, 1992, p. 12). This tendency towards marginalizing women and even disempowering them could be dated back to these pre-Islamic years.

Ahmed argues that Islam as a religion advocating "ethical egalitarianism", cannot be responsible for the frequent practice of women abuses in the Arab countries (Ahmed, 1992, pp. 64-66). She manifests citations from the Qur'an to verify that Islam had proclaimed equality for all people regardless of their religious, ethnic, or racial background, hence, it cannot be responsible for the gender abuse directed against some Arab women: "For Muslim men and women, For Believing men and women, For devouted men and women, For true \{truthful \} men and women, For them has God prepared Forgiveness and a great reward” (Surát, 33:35).

In her book, Women Claim Islam: Creating Islamic Feminism Through Literature, Miriam Cooke hails a rising trend made by talented Arab women writers who collaboratively form an unfamiliar mode of feminism questioning the entangling roots for the discrimination committed against Arab women. In The Veil and the Male Elite: A Feminist Interpretation of Women's Rights in Islam, Fatima Mernessi makes prolonged investigation into the accountability of Prophet Mohammed's Hadith for condemning the Islamic tradition as a "misognist" (Cooke, 1999, p. 71). Mernessi assumes that there is a basic difference between El Shariaa and the predominant Arab social customs (Cooke, 1999, p. 71). She namely mentions two of the men who were assigned in the epoch suceeding the death of Prophet Mohammed to accumulate and interpret his hadith: Abu Bakra and Abu Hurayra. She has reasons to be skeptical over their integrity. "The second Caliph Umar Ibn al-Khattab had ordered that Abu Bakra be flogged for false testimony!” (Cooke, 1999, p. 72).

The Algerian novelist Assia Djebar made the same inquiry over those men who "felt free once the prophet was dead to quote him opportunistically” (Cooke, 1999, p. 72). Abu Hurayra was equally of suspectable reputaion; "several times he was recorded as having been corrected by Aisha" (Clark, 2007, p. 72). Mernessi concludes that "the male elite in Muslim countries supports an interpretation of the Qur'an and Hadith which makes Muslim women at best second-class citizens” (Cooke, 1999, pp. 70-75).

As Islamic feminists seek equality between men and women in the sacred verses of the Qur'an, the authors of the following narrative works exert the same effort in breaking the ground under the assumption that all gender abuse is blessed and cherished by the religion of Islam.

To begin with the Syrian novelist Ulfat Idilbi, her personal biography as presented in The Guardian would tell about her outstanding personality. She was born in Ottoman Damascus in November 1912; died March 21 2007. As a self-educated and a nationalist, she is an eye-witness and a participant in the national movements of 
that period. Throughout her life, Idilbi gave centrality to feminist and gender issues; she left her maiden name rejecting what she saw as "a patriarchal custom and insisted on being known as Mrs. Idilbi” (The Guardian, 4/18/2007).

In 1980 Sabriya was first published in Arabic as Dimeshq ya Basmat al-Huzn and in 1995 was translated into English as Sabriya: Damascus Bitter-Sweet, and published in the same year. The opening of the novel is rather unconventional. It includes the flashback technique beginning with the climatic event of the novel; the death of the protagonist, Sabriya. It is divided into various integral episodes; each episode builds upon the preceding ones.

The title of the novel and the protagonist's name bear close implication on her fate. Sabriya exclaims about the way her name anticipates the great burden of suffering and endurance she has to put up with: "did they call me Sabriya because it means long suffering ... what is left but the undertaker and the tomb?” (Idilbi, 1995, p. 6). The female protagonist Sabriya who is denied her opportunity of love and education on gender-based reasons is similarly enthused about such claims. She is an aspiring and full of zest woman, paradoxically, she eventually commits suicide. The narration gradually unfolds the mystery of her suicide. The sequence of time of Sabriya punctuates the conditions of Arab women in Damascus, Syria, in the early half of the last century a rigidly conservative society. Feminist movements advocating for the woman's right for secondary and university education struggled with the counteraction of the reactionaries. In Egypt, Huda Shaarawi, in Lebanon Ibtihaj Kaddura, and in Syria Adila Abd al-Qadir al-Jazairi, courageously lifted the veil (Badran \& Cooke, 1990, p. 360).

The setting depicts the Arab traditional domestic life of that period. It introduces a traditional Arab house with the "liwan" looking over the courtyard of the house. The beauty of nature coinciding with the blossoming of spring is incongruent with the solemnity of the occasion taking place. It is the funeral of Abu Raghib, the owner of the house, Sabriya's father, and the grandfather of Salma, the protagonist's niece who takes the first part of the narration as a commentator. Salma is denied attending her grandfather's funeral ceremonies. This was among "the prescribed limits beyond which a girl was not expected to go" (Idilbi, 1995, p. 3). Yet, she is well-informed of all the grown up events through the cobweb; a small room on the roof of the house facing the courtyard. The incongruity is made clear, when Salma says that the preparations made for the funeral bring into her mind the dream or the image of her own wedding.

As the novelist gives vivid description of Arab-Islamic funeral rites, she highlights through the glossary preceding the text of Sabriya some idioms and names with an ethnic background. The name of Nasiba Bint Ka'ab, a heroine of the early Arab Muslim history whose name is reputed for tending the wounded of the battle of Uhud. There is also the name of Khawla bint Al-Azwar whose name brings the memory of the daringly unprecedented courage of an early Arab feminist figure. She, as enlisted by the novelist, "assumed the clothes of her slain brother and fought on" (Idilbi, 1995, p. 8). As Idilbi signifes, this might refute the reputation Islam has gained as being hostile to women's liberation. These two early Arab Muslim women figures denote that Islam, in its prime and vigorous days, did accept some gender norms of feminine potence within a less modernised social context. Astonishingly, there are abundant examples of potent women who acted as warriors in the battle of Yarmouk "Azdah bint al-Harith ... Hind bint 'Utbah, on the Meccan side at Uhod but now a Muslim herself and mother of the Muslim governor of Syria ... along with her daughter, Huwairah” (Ahmed, 1992, p. 70). 
From the very beginning of Sabriya, Ulfat Idilbi poses her thesis in a series of complaints articulated by Sabriya over the social restraints disempowering the Arab women:

I am helpless ... There are generations behind the way I have been brought up... Was women in this country created only for worry and chore? ... They are not permitted either to earn or to learn. Over the ages, religion, customs, and tradition have imposed taboos with roots so strong in our hearts that they are venerated. (Idilbi, 1995, pp. 7-39)

Idilbi fleshes out some female characters whose singularity amazed the Damascene society of the time. Sabriya is much of a feminist herself. She is one of those females who might be described as "veering from the norm” of their time (Badran \& Cooke, 1990, p. 16). The character of Sabryia’s aunt, Um Rashed is admired by Sabriya as she "ignores conventions and tradition" (Idilbi, 1995, p. 61). Sabriya feels remorse for the inability of her mother to cope with her sister's code of daring behavior. Um Rashed is also praised by Sabriya's father for her manly strong will as she manages to run her husband's business. She outgoes her womanly roles; she used to "disguise herself, dress up in men's clothes, put on a kuffiya, and ride a horse with her son Rashid behind her" (Idilbi, 1995, p. 61).

In this sense, Um Rashed is different from the stereotype of the Arab women embodied by Sabriya's mother, Um Ragheb, who is described as "the paragon of virtue and modesty" (Idilbi, 1995, p. 127). Sabriya repeatedly incites her to rebellion: "Mother. A woman of your age, old enough to be a grandmother, having to seek permission from her husband whenever she wants to leave the house!” (Idilbi, 1995, p. 87). Her mother’s identity is referred to only in terms of her motherhood. Viewed in the light of modernity, Sabriya's mother is typical of the mainstream of the Arab women.

Idilbi clarifies how Sabriya's national involvement challenged the customs of the Syrian society, then, which preserved political involvement only for men. She also brings to light an act of honour preservation grossly practiced in the Arab societies as the family fetches the mid-wife Umm Fawzi to check Sabriya's virginity.

The veil is another custom-related issue treated in the novel as a shackle handicapping the heroine. The abandonment of the veil was the basic demand of the frankest advocates of social change in the Arab world. Naziq al-Abid and the few women who shared her views, all from the Syrian upper-class, saw it as a badge of restrained femininity. Inspired by the Egyptian activist Huda Shaarawi (1879-1947), who led the anti-veil movement at a train station in Cairo in 1923, they took part in anti-French marches, with a group of other unveiled ladies and strongly campaigned to "root the veil from society" (Moubayed, 2005, p. 2006).

The connotations of the veil as conceived by the fundamentalists of the time is reflected in Sabriya as a signifier of the Arab as well as the Islamic identity. It has been conceived by the conservatives as a sign of respect for this identity and kept the Arab women differentiated from the excessive and licentious life of the West. The heroine considers it as crippling and a sign of women's bondage.

Idilbi signifies that the common female stereotype usually encouraged in Arab communities must be lacking in competency and initiation. She portrays the personality of her protagonist Sabriya in a distinct way excelling in both traits. Her brother Sami warns her "Take care you are not near any marriage-makers. If you have to, you must know how to keep them at a distance” (Idilbi, 1995, p. 54). Idilbi includes another minor example of an impoverished female character, Um Abdu who had to work as a servant to raise up her children. Sabriya is not content to show dumb signs of sympathy to Um Abdu; she secretly gives her the new bracelet to feed her children. 
The novel provides examples of male exploitation practiced against women. Sabriya's two brothers evaded their familial duties and left her to perform what they assumed a strictly female role.

The protagonist of Sabriya finally takes a fatal decision; she hangs herself in the tree of her house. By taking such a horrible act, she makes a fierce condemnation of her society. Her question rings, "When will the male myth be expunged from our society?” (Idilbi, 1995, p. 160). When alive, she is kept inarticulate. Her brief words and deviant behavior make little sense for her niece Salma. Sabriya is given the power of articulation after she passes into another world. Her first person narration is lucidly included in a diary. The diary reflects the distribution of gender roles in the house which makes Sabriya and her mother wake up before dawn to finish cleaning and getting breakfast ready for the male members of the family. Her family makes the perfect microcosm of the patriarchal Arabic family structure of the 1920s.

It is not Islam or the Quran which prevents women from being fully engaged in the public spheres of education and paid professional work. All the authority and power are held by the male members. Sabriya writes in her diary: "In our country they train a girl, as soon as she is aware of herself, to serve the men, be it her brother, husband, or son. So when she has grown up she feels that such servitude is part of nature” (Idilbi, 1995, p. 44). Throughout this recollection, Idilbi unfolds two main points of view; manipulation of women in the Arab societies had been bred out and firmly established under the name of religion, nevertheless, there have always been some Arab women who happened to resent female subjugation.

This can be the same point of departure in Fadia Faqir's Pillars of Salt. Faqir is one of the leading contemporary Arab women writers. She was born in Jordan in 1956. She currently teaches Arabic literature at Durham University. Being raised in the conservative Jordanian society, she has certainly experienced types of gender biases targeted against women. Also, her feminism was forged from her practical interaction as an editor of a collection of testimonies by Arab women novelists. She is well informed about the grievances and discriminations practiced against women on the basis of gender.

Pillars of Salt, Faqir's second novel, dwells on the position of women in the Jordanian society in the 1920s. It tackles, among other themes, the treatment of the insane women in Arab societies. In Pillars of Salt, Faqir intermingles the private and public spheres together. The novel deals with the national fight of the Jordanian Bedouins against the British troops. The title of the novel provokes several connotations. Salt holds multiple implications; it implies repressing patience, the faculty which has been exhausted by the two women protagonists. In the novel it has another connotation of sterility. It illustrates the futility as well as complexity of the factors that constitute gender identities.

The opening of Pillars of Salt reminds the reader of the ancient form of the Arab storytelling to insinuate an air of antiquity, and is presented in an apocalyptic point of view, thus reflecting the repression of women and their restrained and desperate attempt to survive in the culture that does not recognize their human dignity.

The setting is diverse combining a place of tribal nature, with unfamiliar historical and geographical background. The narrative style is characterised by the popular nature of tales from oral tradition. An astonishing air of ethnicity and religiosity surprises the reader from the very opening of the novel. Beside her son Haytham, the novelist dedicates her work to her tribe "the Ajarimah". The text of the novel is forwarded by a historical chronology dating back to 1187; the year Saladin al-Ayyuby defeated the Crusaders. It is a reminder of an important era of the Arab national history. 
The structure of the novel consists of sections seemingly conveying independence as they include three narrators for the episodes of the novel; Sami al-Adjnabi, Maha, and Um Saad. Sami al-Adjanbi tells Maha's story with a different style and of different a perspective. Um Saad is left to tell her story on her own. An unseen thematic thread combines the two stories forming one whole integral picture of the injustice that women in Arab societies suffer from. In the novel, the two women who are placed in the mental hospital in Jordan share the complicated stories of their lives with each other. The first story of Maha is set in Hamia, the village where the tribe of Bani-qasim settled. The novel begins with a story teller narrating a tragic popular tale:

Maha was her name. A deer that had been roaming the deserts of Arabia since Eve, made out of our father Adam's crooked rib, was cast out of Heaven. Maha. A charming woman who challenged and surrendered. Some say that Maha was as pious and pure as Rabaa al-Adawiyya, the mother of Sufis and Allah's chosen songstress. ... I say that Maha was a shrew who used to chew the shredded flesh of mortals from sun birth to sun death. (Faqir, 1997, p. 2)

The opening of the novel brings an ethno-religious background. It commemorates the chapter with Verse from the Qur'an. The narrator deliberately links Maha to the name of Rabaa al-Adawiyya which brings to memory an ascetic image of transformation from utter sin to divine repentance. The timing of the events, as mentioned by the narrator, was the first night of Ramadan. Then, the narrator Sami al-Adjnabi introduces himself as "the best storyteller in Arabia and the oldest traveler in the Levant" (Faqir, 1997, p. 1). His version of Maha's story, at first seems quite reliable, then it looks hard to believe and even distorted, since there is Maha's own narration to discredit it.

Like those of Sabria: Damascus Bitter Sweet, the female characters of Pillars of Salt are as illiterate as the bulk of the Arab women in the 1920s. Faqir interweaves the threads of two separate lives of Maha and Haniyaa together with the lines of suffering and depravity. The two women find themselves locked in that desolate asylum. They have different temperaments. Um Saad is Maha's roommate at Fuhais hospital. She is an urban, cheerful, talkative woman. She had received some elementary education in her childhood, had been to movies, and was less-secluded than Maha. At first, Um Saad treats Maha snobbishly bragging, "I am an urban woman from Amman. I refuse to share the room with a grinning Bedouin” (Faqir, 1997, p. 6). But Maha's compassion and genuine care could win Um Saad's love and admiration. The two women share each other's misery.

Faqir manifests geography and religion in the context of history and politics to highlight a serious gender problem. Like that of Sabriya, the geography of the place in Pillars of Salt plays an integral role in the formation of the characters. The rigidly tight and conservative domestic sphere of Pillars of Salt would hardly allow a change in the attitude towards women. But the Dead Sea which is usually present in Maha's world had been a liberating as well as a healing agent. At the beginning of the novel, she was contemplating the risk of responding to Harb's date near the Dead Sea. On her wedding night, Maha tries to acquire very scanty allowance of her dream; she asks Harb to go with her to the Dead Sea where they spend a dreamy night. When Maha walks beside it in her worst moments of tension, she thinks “as long as the Jordan was beside me I would be fine” (Faqir, 1997, p. 162).

In her anthology Opening the Gates: A Century of Arab Feminist Writing, Margot Badran concludes that one of the difficulties which Arab women had to confront was to "pioneer their feminist expression in agrarian societies, more recently experiencing modern urbanization, and in societies where religion has remained an important regulator of everyday life and a source of identity” (Badran \& Cooke, 1990, p. XXXiii). Pillars of Salt 
gives several examples that the geographical nature of the novel which denies any exposure to other cultures has impacted the female characters of the novel and has paid them great injustice.

The same as Sabriya: Damascus Bitter Sweet, Pillars of Salt demonstrates the problem of illiteracy among Arab women during that period. Maha is quite aware of her limitations: "I realized at that pitch-dark moment that I was just a simple peasant woman. .... I did not know how to operate the machine which cooks meals in the kitchen” (Faqir, 1997, p. 162). But her shortcomings are not attributed to her gender type rather than to the inadequacy of her social restrictions. This is articulated in the way she queerly meditates the word identity: “identity? What is identity. I think I have none” (Faqir, 1997, p. 80).

Despite her seclusion, Maha is much more intuitively intelligent than what is expected of her as a Bedouin. She tries to make up for this deficiency as she punctuates her life and existence with nature. She is mostly attached to the earth and its secrets more than people. She also proves herself capable of generating ideas. She listens attentively to the radio her brother has bought, she vaguely understands that the program addressing the peasants is instructing them against plant infection. She is inspired by the speaker's words to run to her brother's room to beg him ask Samir Pasha to bring her some insect killers.

Spinning was neither a sheer part of femininity, nor a time consuming activity. The half-finished carpet remindes Maha of her's and her mother's unfulfilled dreams. There was always her mother's voice urging her, "Please complete what your grandmother and I have started" (Faqir, 1997, p. 15). "Weaving was an urge to transform the dirty fleece" (Faqir, 1997, p. 14). It is her magical tool into the world of dreams. She was eager to spin on the night of her engagement, "My palms started itching for the spinning wheel”, but she was not allowed. The old women regard it as "a bad omen” (Faqir, 1997, p. 24).

Like Sabriya: Damascus Bitter Sweet, Pillars of Salt exposes the defects of a bigoted and male-biased society. The male characters, as in reality, gained in vertical strength and control. Boys are regarded as future bread-winners whereas girls are considered a financial burden. In her revolts against Daffash’s slaps, Maha's mother would say to her "What do you expect? He is a boy. Allah placed him a step higher" (Faqir, 1997, p. 33). If the burden of the Arabic bigoted legacy has been supported by the Islamic texts, as Ahmed speculates, how come that many incidents about the immense esteem Khadija, the Prophet Muhammad's wife, "this mature and wealthy woman "had frequently received from the Prophet and from the society at large" (Ahmed, 1992, p. 47).

In Pillars of Salt, upon setting Daffash against his female counterpart, Maha, he would fail in terms of personality, diligence, national zest, and familial responsibility. Daffash seems to fit the negative model of masculinity: aggressive, dominant, severe, and unemotional. Maha tries to describe his ineffectual personality to her companion Um Saad: "My brother, the son of my father. He was like winter sun. Now you know him and now you don't. Ruthless and kindness kneaded together” (Faqir, 1997, p. 72).

Faqir gives Maha an active, yet restrained feminine model alien to the rest of females of her society. She manages to perform some roles, “I’ll compensate you, father” (Faqir, 1997, p. 21). Unlike Sabriya’s vulnerable mother, Maha’s mother passes her some binary values; along with her tribal wisdom comes her incitement. She taught her how to "hold the axe, when she was ten years old, she managed single-handedly to plough her father's field, to cook and feed twenty tribesmen, and to spin some threads for her mother” (Faqir, 1997, p. 26).

The same as Sabryia: Damascus Bitter Sweet, Pillars of Salt exposes the terrible consequences of misinterpretation of religious texts. It reveals another form of physical abuse of women under the habit of honor 
preservation committed in the Arab communities. In her article "Intrafamily Femicide in Defence of Honor: The Case of Jordan”, Faqir writes:

Girls or women can sully their family's honour and their reputation until they get married and become the responsibility of their husbands. In Arab societies, women should remain mastura (hidden, low-profiled) a term which implies physical and psychological confinement in the private and public space. (Faqir, 2001, p. XXXVI)

What increases Maha's dismay is that the society would not show mercy with a childless woman. She counteracts her fears speculating that "I was childless and must be a perfect housewife and mistress" (Faqir, 1997, p. 69). She tries another version of productivity as she indulges herself in persistently defying the salty soil and planting it. Faqir's language is endowed with eloquence. Her prose is more like poetry in its rhythmical effect. To illustrate Maha's profound grief, Faqir uses several figurative words derived from the folk songs of the Bedouin to illustrate Maha's complains about her luck "the garment I was wearing was rent by days of sadness" (Faqir, 1997, p. 118). Maha's growing feeling of helplessness in front of the crowd is tenderly articulated to her son "Your father used to be the best horseman in the tribe, your grandfather used to be feared by all our enemies and your mother... She is like an earthworm which crawls under the sand in order not to be seen” (Faqir, 1997, p. 183).

There are many examples of gender physical and sexual abuse in Pillars of Salt. The character of Daffash, Maha's brother is “a womanizer and city-worshipper” (Faqir, 1997, p. 21). After raping Nasra, Maha’s friend, the bewildered girl ran for Maha’s support. "She asked me. She even tempted me... You stopped struggling. And lay back” (Faqir, 1997, p. 12). This sentence tells a lot about the dual bigoted attitudes held by Arab males towards women. Maha herself receives the same abuse on her way home after attacking the Pasha and making a scene of her brother in front of their guests. Sheikh Talib, an old man of a seemingly pious pose, tries to rape her "poor widow... my wife is old and blind ... I always thought of you. Strong Maha” (Faqir, 1997, p. 163). Maha shrinks back in horror then kicks the man to the ground and thought “I hadn’t harmed anybody in my life. I even carried the beetle to safety on my broom ... The cries of Raai could be heard. ... The village was blind” (Faqir, 1997, p. 163).

Maha does not realize that Sheikh Talib's sensual desire for her would eventually lead to her insanity. The novelist unveils how, customarily, Arab communities allow the masculine excessive self-indulgence. With all his reputable wisdom, Sheikh Nimer himself fails Maha’s expectations and scolds Nasra saying “And you shouldn't have tempted him” (Faqir, 1997, p. 13). He proves himself to be as bigoted as the rest of his male fellows.

Faqir has endowed the female protagonist with some national zeal which might seem incongruent with her illiterate background. She makes an acute contrast with Nasra. She is more serious, indignant resolute, and more of a rebel. Fit to be "a free mare" as described by Harb. Maha, this Bedouin illiterate girl rejects all types of colonization "Occupation was like a thin cloud, which was blown away by the wind. The orchards never stopped bearing fruit, the sky remained clear and blue... the spirit of the Arab resistance (Faqir, 1997, p. 195). But soon, Maha adequately justifies her enmity; it reminds “with Harb, the twin of my soul, my teeth” (Faqir, 1997, p. 196). Amidst a banquet held by the Pasha, Maha discovers that she has been cooking for the colonists who made her a desperate widow, and made of her baby a poor orphan. She flings into an outburst of anger "foreign killers ... den of foxes who had eaten my husband’s flesh” (Faqir, 1997, p. 162). 
Later on, Maha celebrates the departure of the English forces, unaware that a more savage plundering colonialism will soon steal her away. The catalyst moment in Maha's life occurs when her brother comes to the farm, obliging her to sign a deed granting him the land and house she has sweated to sustain, or else to marry her off to Sheikh Talib. The situation gets severely complicated. Maha's confrontation with Daffash focuses on the fragility of women's situation in Maha's tribe. Although they share her the same experience of oppression and exclusion, but the women: "stood behind doors and windows and peeped at the woman who spent a night on her own in the mountains” (Faqir, 1997, p. 216).

In her final battle against Daffash, Maha is to confront an overall male-biased society. The whole village, with few exceptions, is keen to force Maha into that marriage. Only Tamam, Hamda, Nasra, and Morgan support Maha in her misfortune. Haja Halal, the midwife of the village, condemns Maha saying "I will open my mouth and spit on Maha's face... She is a disobedient girl and deserves to be beaten up” (Faqir, 1997, p. 165). The novel shows the difficulty of an individual female to confront this collectiveness of the bigoted mass. They are motivated by a deep-rooted legacy of female subjugation. Maha's resistance threatens their authority. When they fail, they lock her in an asylum. Her brother Daffash takes possession of all the things she dearly loved and strived to sustain. The asylum exposes another episode of the humiliation that psychopathic women receive. Um Saad describes this to Maha: "Maha, sister, in an old German car, they brought me to this place. Without my hands, I am not even with a piaster. ... I was like a hooded falcon: blind, unable to fly” (Faqir, 1997, p. 206).

The character of Nasra in Pillars of Salt is fleshed out to be Maha's counterpart. She infuriates Maha with her fragility and dumb passivity. She even prevents Maha from pulling the trigger against Daffash, which makes Daffash's version of the rape a reliable one. Maha is terribly aware that reputation for females is everything: "My friend has lost her virginity, her honor, her life. She was nothing now. No longer a virgin, nothing. A piece of flesh. A cheap whore" (Faqir, 1997, p. 11). Maha, then, thought: "I realized how high were the mud walls imprisoning us” (Faqir, 1997, p. 13). There was a strong feeling of anger, protest and rebellion in Maha's character probably springing the writer's personal experience in Nasra which is also modeled on some real Arab women who pay their lives in the vain name of honour. They lie in the centre of Fadia Faqir's social concerns. In her article "Intrafamily Femicide in Defence of Honour: The Case of Jordan", Faqir witnesses cases quite similar to that of Nasra. The female's submissiveness and even compliance with the male's tyranny is incarnated in Nasra. Despite all his abuse of her, she once more saves Daffash's life when he took Saleh's wife to the café; Nasra flings into Maha to warn him against Saleh's furious search for his wife.

Faqir delineates the character of Um Saad as the parallel stereotype of passive and oppressed femininity of Nasra, which stands in stark contrast to Maha's character. The portrayal of Um Saad reminds of the belittling capsulation of women as "sexual objects, whose value, unlike men, decline with age” (Spender, 1991, p. 36). Through Um Saad, Faqir brings out social, historical, and geographical facts to the foreground. She recollects her past, “Amman was like a spacious Ottoman prison” (Faqir, 1997, p. 71). Her narration reveals how modernization crept slowly into the Jordanian society: "The narrow streets were flooded with flickering light... The crooked street lamps are no more... Amman has electricity now” (Faqir, 1997, pp. 71-72). Maha spontaneously interrupts her, "Electricity. My village has none”, Um Saad replies, “Darkness is merciful. Light is cruel” (Faqir, 1997, p. 72). Um Saad's dislike of light could be that darkness allows her fancy to slip away, or, it could be that her life with that sign of modernity becomes even worse than before. She bewails her ill-fortune: 
"My life is like scattered flour in a thorn field” (Faqir, 1997, p. 81). She has been experiencing gender injustice ever since her birth, "They just beat me without a reason. I will never forget the moustache of my father. ... Two eagles could sit on his bushy moustache” (Faqir, 1997, p. 79).

Faqir refers to some ethnic remarks through the very brief love affair between Um Saad and her Circassian lover Mohammed. Astonishingly, Mohammed was not allowed to marry her because he was a Circassian; the chronology forwarding the novel has detected the period from 1878 to 1909 when the Circassian fled the religious persecution of the Russians to enjoy religious tolerance in Transjordan. She marries a man whom she loathes. She has to forget the one man she loves and tolerates an older man to adapt herself to a new life. Ultimate acceptance of male domination is part of a cultural lesson she has been taught ever since her birth. Her mother used to call her "Haniyyeh, where are you, broken-neck? ... because I, the first-born, was a girl and not the boy she had longed for" (Faqir, 1997, p. 95). She used to listen carefully to the popular song "Hey Saideh, listen to your master I am having a bath. Obey your master. I am cooking. Obey your master". She has been adapted to male subjugation. When her father rejects her marriage to Mohammad, she becomes inarticulate. She adapts herself to the disgusting smell of the sheep stomachs he used to bring home every night. She has got eight sons to raise and serve. To read what Um Saad's neighbors comment on her wish to have a baby girl, her neighbors said to her, "Thank God he is a boy. Girls are a worry until you are in the grave” (Faqir, 1997, p. 129). The statement is meaningful. It sums up a general belittling attitude targeting women.

For the rest of her life Um Saad becomes indulged in a process of endless cleaning and cooking. She describes how her sons used to mock her terrible exhaustion "The Hajja has sat down and only Allah will make her get up" (Faqir, 1997, p. 158). Um Saad is unlike Maha who has been endowed with a great deal of self-indignation. Her mother-in-law, Tamam, asks her "Maha, you think you are different from the women of the tribe” (Faqir, 1997, p. 135). Um Saad's physical exhaustion and lack of appreciation from all around her caused her terrible lack of self-confidence. She even depreciates her own femininity saying "I hate my body" (Faqir, 1997, p. 122). She was naively obsessed by the then incarnating model of femininity the Egyptian actress Hind Rustum.

Colloquialism and popular code of thought typify the speeches of Um Saad. Unlike the sublime poetic classical Arabic spoken by Maha, Faqir lets Um Saad use the language of the slums. She quotes an expression of a sexual implication used by a neighbor, fostering the feeling of inferiority of women of her class "We are vessels... that is how men see us. That's what men care about” (Faqir, 1997, p. 159). When Maha asks her if she likes Abu Saad, she gives a meaningful and painful answer implying resignation, "I loved the scent of honey suckle, but I tried hard to get used to the smell of black iris” (Faqir, 1997, p. 158). Her talk exposes, beside gender oppression, some sense of ethnic inferiority; a lack of any ancestral background "because I am an immigrant daughter, people think that I come out of a wall. No family tree or past. So nobody would propose to immigrants Abu Saad and me. The dropouts for the outcasts. The refuse for the junk” (Faqir, 1997, p. 123). When her husband brings his young bride, she bursts into rebellion; he offensively replies and beats her. She repeats his words "because of my grey hair" (Faqir, 1997, p. 179). Rage has swarmed up into revolt, "red is the colour of my heart... of blood" (Faqir, 1997, p. 179). Then she declines into a state of subservience and subjugation.

For Um Saad, singing functions in the same equivalent healing way as spinning does for Maha. "My father used to call me 'Haniyaa the dreamer'” (Faqir, 1997, p. 71). She tries to substitute her ugly reality with dreams. 
Yet, eventually it becomes of no use. When her husband has brought his new bride to her own house, she reacts in a slave-like manner, but soon she is to fall into a fit of psychological collapse, taken as real madness.

The style of narration of the two novels tells of the writers' talent and artistry. The two novelists are less personal and more national and social in approach. They reflect the daily realities of the Arab societies. They have stepped into a realm that has been assumed as only preserved for men.

The main female protagonists of the two novels evoke controversy in the way they differ from the conventional gender patterns. They earnestly try to defy their terrible reality with productivity and fertility. The two heroines, Sabriya and Maha, are rebels against both colonial and gender oppression. They set into action rejecting all aspects of bigoted hierarchy. They defy the ugliness of their real world heading into a world of their own.

Both Sabriya and Maha are forced to retreat into two irreconcilable world of dream and reality. As the two female protagonists of Pillars of Salt and Sabriya are forced to ignore their femininity to live a deprived life, they make up for their frustrated dreams with daydreaming. They are blessed with powerful character traits which, if given the chance, would spare them much suffering and secure them a more prosperous life.

Violence and manipulation are the common male character aspects castigated by Idilbi and Faqir. Ragheb in Sabryia and Daffash in Pillars of Salt serve paradigms of failure. Their only means for self-fulfillment is to subjugate their female counterparts. The sons in the two novels are supposedly assigned the role of breadwinner who leave the whole burden to their female counterparts. Contrarily, they only appear to foster their sisters' economic and emotional depravity.

In both Sabriya and Pillars of Salt, a female solidarity always seemed to exist despite all obstacles. If the heroines fail to integrate themselves into their patriarchal environment, patriarchy is to be blamed for their fates. It lies behind their drawbacks; Sabriya's final resignation, Maha's and Um Saad's illiteracy, and Um Saad's humiliating subjugation. The two novels raise inquiries about the responsibility of the Shariaa for the gender abuse of women practiced in the Arab countries. Leila Ahmed, Assia Djebar, and Fatime Mernessi demarcate how such hierarchal structure has been formed in Arab Islamic countries via edifices of historical, national, and ethnic interaction. They devote their academic interests to severe the Shariaa from all the misconeptions and disentanglement of the tradition. As they fulfill this assignment, they verify many practices attributed to the religion of Islam.

To conclude, the two novels capsulate Idilbi's and Faqir's genuine concern with the unjust condition of women in the Arab world. In their writings, they both indict the male-biased assaults directed against Arab women. Both Pillars of Salt and Sabriya: Damascus Bitter Sweet give true pictures of the lives of Arab women. The two novels exhibit how some of the female characters try to maintain a sense of empowerment, self assertion, social and economic liberation. They also demonstrate some male characters who, out of self indulgence, exempt themselves from performing certain tasks; nevertheless, they play the roles which satisfy their feeling of superiority and dominance. Likewise, the two novels reflect two relatively similar ethnic and historical backgrounds. They demarcate an important phase of social as well as political change in the Arab world.

This paper proposes that much of the gender inequalituy practised in the Arab societies is commonly attributred to religion might be rooted in the tradition. Such entanglment is elequently delineated in both Sabriya: Damascus Bitter Sweet and Pillars of Salt. 


\section{References}

Abu Odeh, L. (1993). Post-colonial feminism and the veil: Thinking the difference. Feminist Review, (43), 26-37. Issues for Feminism, Spring. Retrieved from http://lawreview.law.ucdavis.edu/articles/Vol39/Issue3

Ahmed, L. (1992). Women and gender in Islam: Historical roots of a modern debate. New Haven, Connecticut: Yale University Press.

Badran, M., \& Cooke, M. (1990). Opening the gates: A century of Arab feminist writing. Bloomington, Indiana: Indiana University Press.

Barakat, H. (1995). The stone of laughter. (S. Bennett, Trans.). (1st American ed.). Brooklyn, New York: Interlink Books.

Clark, P. (19 April 2007). Ulfat Idilbi: Renowned Syrian fiction writer, lecturer and feminist. The Guardian.

Cooke, M. (1999). Feminist transgressions in the postcolonial Arab world. Critique: Critical Middle Eastern Studies, 8(14), 93-105.

Faqir, F. (1997). Pillars of salt. New York: Interlink Books.

Faqir, F. (1 February 2001). Intrafamily femicide in defence of honour: The case of Jordan. Third World Quarterly, $22(1), 65-82$.

Lips, H. M. (1988). Sex \& gender: An introduction. Mountain View: Mayfield Publishing Company.

Milani, F. (October 22, 2006). Coverings uncovered. The Washington Post.

Moghissi, H. (1999). Women, war and fundamentalism in the Middle East. In The limits of postmodern analysis. London: Zed Press.

Moubayed, S. (Nov. 14, 2005). The face that launches a thousand ships. Mideastviews.

Provence, M. (2005). The great Syrian revolt and the rise of Arab nationalism. The modern middle east series. Austin: University of Texas.

Rakha, Y. (1999). Hoda Barakat: Starting over. Al-Ahram Weekly, 25 Nov.-1 Dec. 1999.

Shabaan, B. (2000). Documenting women Arab novelists leads to re-writing history. Al-Jadid, 6(33).

Shirazi, F. (22 Oct. 2006). The veil unveiled. The Washington Post.

Spender, D. (1991). Women of ideas and what men have done to them. London: Ark Paperbacks. 